\title{
Efektifitas Peran BPKP dalam Pembinaan dan Pengawasan Implementasi Sistem Informasi Manajemen Daerah (SIMDA)
}

\author{
Arif Fajar Wibisono \\ Universitas Islam Indonesia \\ Jl. Kaliurang KM 14,5 Yogyakarta \\ ariffajarwibisono@uii.ac.id
}

\begin{abstract}
The purpose of this paper is to analyze the effectiveness of Indonesia's government internal auditor Badan Pengawasan Keuangan Pembangunan (BPKP) role on supervison dan controlling on implementation aplication Sistem Informasi Manajemen Daerah (SIMDA). This research is a qualitative research by using descriptive analysis and interview with senior auditor in BPKP Yogyakarta, he is a coordinator ini goverment accounting region. This result are minimum human resources, the low government budget, and employee are difficult to changing to the new working method made be the problems in efektiveness of supervison and controling implementation SIMDA. The limitation on this research is only the one kind of supervison and controlling on SIMDA aplication. The future research must be another prosedures supervision and controlling in BPK and more object research.
\end{abstract}

Key words: BPKP, Efektiveness, SIMDA

\section{PENDAHULUAN}

\section{Latar Belakang}

Badan Pengawasan Keuangan dan Pembangunan (BPKP) adalah salah satu lembaga pengawas internal pemerintah yang memegang peranan penting dalam pengawasan. Sejak Orde Baru (Orba), lembaga ini diberi wewenang yang besar untuk melakukan pengawasan keuangan dan pembangunan serta menyelenggarakan akuntabilitas pemerintah di Indonesia. Sesuai dengan visi BPKP sebagai Auditor Presiden yang responsif, interaktif dan terpercaya untuk mewujudkan akuntabilitas keuangan negara yang berkualitas dalam mentransformasikan manajemen pemerintahan menuju pemerintahan yang baik dan bersih serta sesuai amanat PP 60 tahun 2008 pasal 59 ayat (2) dan Inpres Nomor 4 Tahun 2011, BPKP, dalam hal ini Deputi Pengawasan Bidang Penyelenggaraan Keuangan Daerah, memandang perlu untuk memfasilitasi Pemerintah Daerah dalam mempersiapkan aparatnya menghadapi perubahan, mendorong pelaksanaan tata kelola keuangan daerah sesuai dengan peraturan yang berlaku, efisien, efektif, transparan, akuntabel, dan auditabel. Hal ini penting guna meningkatkan kualitas Laporan Keuangan pemerintah daerah menuju terwujudnya good governance.

Laporan keuangan pemerintah daerah saat ini diwajibkan mengikuti Standar Akuntansi Pemerintahan sesuai Peraturan Pemerintah No.71 Tahun 2010. Peraturan Pemerintah ini menjadi dasar penyusunan laporan keuangan pemerintah daerah dengan disempurkanan melalui Peraturan Menteri Dalam Negeri No 64 tahun 2013 yang mengatur secara teknis pembuatan laporan keuangan pemerintah daerah dengan menggunakan basis akrual. Tujuan diterapkannya hal tersebut adalah peningkatan kualitas informasi laporan keuangan. Peningkatan kualitas informasi melalui perbaikan dari sisi transparansi dan akuntabilitas

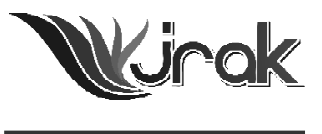

Jurnal Reviu Akuntansi dan Keuangan ISSN: 2088-0685 Vol. 7 No. 1, April 2017 Pp 951-962 
Efektifitas

Peran

BPKP...

952

laporan keuangan pemerintah daerah. Namun penerapan standar berbasis akrual ini memerlukan komitmen dan kualitas dari pemerintah daerah untuk mengimplementasikan dengan baik. Permasalah inilah yang menjadi kendala dimana sumber daya manusia yang dimiliki belum sesuai yang diharapkan.

Guna mendukung kesuksesan implementasi sistem aplikasi tersebut sejak tahun 2003, Deputi Pengawasan Bidang Penyelenggaraan Keuangan Daerah membentuk Satuan Tugas Pengembangan Sistem Informasi Manajemen Daerah (SIMDA), dengan berbgai macam tugas, pertama mengembangkan $/ \mathrm{mem}^{-}$ buat dan melakukan pemutakhiran Program Aplikasi Komputer SIMDA yang berkaitan dengan pembangunan / peningkatan kapasitas pemerintah daerah yang sesuai dengan peraturan perundang-undangan yang berlaku atau dalam rangka pemenuhan kebutuhan manajemen daerah, mengarah ke grand design Data Base Management System (DBMS). Kedua memberikan bimbingan teknik / pelatihan kepada Satgas SIMDA Perwakilan BPKP yang akan ditugaskan dalam asistensi/implementasi Program Aplikasi Komputer SIMDA. Terakhir Membantu Satgas SIMDA Perwakilan BPKP melakukan asistensi implementasi Program Aplikasi Komputer SIMDA pada pemerintah daerah. (www.bpkp.go.id)

Hingga saat ini dalam rangka mendukung dan mengoptimalisasi manajemen daerah pada implementasi standar akuntansi berbasi akrual, Badan Pengawas Keuangan dan Pembangunan (BPKP) telah mengembangkan aplikasi komputer berupa Sistem Informasi Manajemen Daerah (SIMDA). Tujuan dari pengembangan program aplikasi SIMDA ialah pertama menyediakan database tentang kondisi di daerah secara terpadu mulai dari aspek kepegawaian, aset daerah, keuangan hingga pelayanan publik. Kedua menghasilkan informasi yang komprehensif, tepat dan akurat kepada manajemen pemerintah daerah yang dapat digunakan sebagai acuan pengambilan keputusan. Ketiga mempersiapkan aparat daerah untuk mampu menguasai dan mendayagunakan teknologi informasi, dan keempat memperkuat basis pemerintah daerah dalam melaksanakan otonomi daerah.

Program aplikasi sistem tersebut hingga september 2016 telah diimplementasikan pada 425 Pemda dari 542 pemerintah daerah yang ada atau sebanyak $78,41 \%$, terdiri dari:

\begin{tabular}{clcc}
\hline NO. & JENIS IMPLEMENTASI & Januari 2016 & Desember 2015 \\
\hline 1. & Pengguna SIMDA & 425 Pemda & 425 Pemda \\
2. & SIMDA Keuangan & 365 Pemda & 365 Pemda \\
3. & SIMDA BMD & 347 Pemda & 347 Pemda \\
4. & SIMDA GAJI & 69 Pemda & 69 Pemda \\
5. & SIMDA PENDAPATAN & 55 Pemda & 55 Pemda \\
\hline
\end{tabular}

Sumber: (www.bpkp.go.id)

Sebagai lembaga penyelenggara akuntabilitas keuangan negara sudah selayaknya peran BPKP tidak hanya mengembangkan sistem yang baik tetapi juga berperan mendampingi hingga implementasi sistem tersebut dianggap berhasil. Tantangan yang dihadapi BPKP adalah efektifitas perannya sebagai lembaga negara dalam memaksimalkan kewajibannya dalam upaya mencapai tujuan negara yang akan dicapai, khususnya implementasi SIMDA sebagai upaya pemerintah menciptakan laporan pertanggungjawaban yang akuntanbel dan transparan. Maka dari itu penelitian berikut ini berupaya untuk menggambarkan peran BPKP khususnya dalam mengawal implementasi SIMDA.

Berdasarkan uraian latar belakang, maka rumusan masalah dalam penelitian ini adalah:

1. Permasalahan apa yang terjadi dalam proses implementasi SIMDA?

2. Bagaimana upaya BPKP dalam mendampingi dan mengawasi proses implementasi SIMDA? 
Pengawasan menjadi bagian tidak terpisahkan dalam penyelenggaraan negara, khususnya dalam pengelolaan keuangan negara. Keuangan negara merupakan bagian yang perlu diawasi karena jika tidak diawasi akan menyebabkan tidak tercapainya tujuan negara bahkan akan menyebabkan kerugian bagi negara itu sendiri. Segala urusan pemerintah yang berkaitan dengan kepentingan negara, khususnya dalam hal keuangan negara, harus diiringi dengan pengawasan agar berjalan sesuai dengan tujuan dan aturan yang telah ditetapkan. Pengawasan berdasarkan subjeknya dibagi menjadi dua yaitu pengawasan internal dan pengawasan eksternal (Gunawan 2007). Proses pengawasan yang dilakukan oleh BPKP selama ini dibagi menjadi tiga bagian, yaitu pengawasan dilakukan di awal, di tengah, dan di akhir periode. Di awal dan di tengah periode, BPKP melakukan tindakan pre-emtif dan preventif sedangkan di bagian akhir dilakukan dengan represif. Tindakan pre-emtif dilakukan dengan cara sosialisasi dan deseminasi. Tindakan preventif dilakukan dengan cara bimbingan teknis dan asistensi. Sedangkan tindakan represif dilakukan dengan cara audit investigasi.

Selain melakukan pengawasan peran BPKP, peran yang lain adalah melakukan asistensi (pendampingan) kepada lembaga pemerintah yang memerlukannya, termasuk pemerintah daerah. BPKP melakukan asistensi (pendampingan) di pemerintah daerah melalui Perwakilan BPKP yang tersebar di setiap ibukota provinsi di Indonesia. Pemerintah daerah dan Perwakilan BPKP harus menjalin hubungan sebagai mitra kerja. Perwujudan kemitraan tersebut dituangkan dalam suatu Nota Kesepahaman (Memorandum Of Understanding/ MoU). Namun bebrapa penelitian mengindikasikan adanya peran BPKP yang kurang efektif dalam hal pendampingan. Salah satu penelitian menjelaskan bahwa pendampingan BPKP berpengaruh negatif terhadap kualitas audit dari sisi opini audit. Menurutnya pengaruh negatif dapat terjadi karena pendampingan atau asistensi yang dilakukan BPKP kepada pemerintah daerah tidak berjalan efektif (Nuraeni 2010). Pada penelitian yang lain menguji kembali pengaruh pendampingan BPKP terhadap opini dan temuan audit LKPD dan menemukan bahwa pendampingan BPKP berpengaruh negatif terhadap opini audit. Akan tetapi, pendampingan berpengaruh positif terhadap temuan kelemahan SPI dan berpengaruh negatif terhadap temuan ketidakpatuhan regulasi (Wicaksono 2012). Beberapa hasil penelitian tersebut mengindikasikan perlunya evaluasi peran BPKP dalam melaksanakan asistensi atau pendampingan.

Setelah dilakukan pendampingan BPKP akan melakukan monitoring dan evaluasi atas pelaksanaan kebijakan terkait. Monitoring dan evaluasi saling berkaitan dan tidak dapat dipisahkan dimana evaluasi memerlukan hasil dari monitoring yang kemudian akan digunakan untuk kontribusi program. Monitoring dan evaluasi (monev) sangat diperlukan dan penting bagi penyelenggaraan kinerja pemerintah daerah. Monev yang dilakukan BPKP merupakan peran BPKP pada pemerintahan daerah yang diwujudkan melalui program kerja pengawasan yang berasal dari permintaan stakeholder.

Kewajiban BPKP yang tidak kalah pentingya adalah sosialisasi dan bimbingan teknis. Kegitan tersebut merupakan kegiatan konsultasi yang dilaksanakan BPKP di pemerintah daerah. Menurut Standar Auditor Intern Pemerintah Indonesia (2013), konsultasi, sosialisasi, dan asistensi termasuk bagian dari kegiatan pengawasan lainnya yang tidak memberikan penjaminan kualitas kegiatan hanya bersifat konsultasi.(AAIP 2013). Sedangkan, bimbingan teknis tidak dapat dipisahkan dari kegiatan sosialisasi dan terkadang dilakukan bersamaan. Sosialisasi dan bimtek dibedakan dari asistensi (pendampingan) berdasarkan output, proses pelaksanaan dan jangka waktu penugasan. Peran sosialisasi dan bimtek BPKP bertujuan untuk membantu pemerintah daerah dalam memahami dan menghadapi perkembangan yang terjadi khususnya terkait keuangan pemerintah daerah. Sosialisasi dan bimbingan teknis pada pemerintah daerah diharapkan 
Efektifitas

Peran

BPKP...

dapat memperjelas dan mempermudah pemerintah daerah dalam operasionalisasi pemerintahan seperti penyusunan laporan keuangan, pelaksanaan peraturan perundang-undangan dan pengendalian intern. Dengan adanya sosialisasi dan bimbingan teknis yang dilakukan BPKP implementasi SIMDA diharapkan menjadi lebih terpantau.

\section{Sistem Infomasi Manajemen Daerah (SIMDA)}

Kemampuan mengelola informasi secara efektif dalam sebuah organisasi sangat penting karena dapat menjadi dasar untuk memperoleh keunggulan kompetitif. Begitu juga dalam pemerintahan, informasi telah menjadi aktiva tidak berwujud, yang jika dikelola dengan baik dapat digunakan untuk meningkatkan kinerja pemerintahan. Oleh karena itu pemerintah sudah mulai mengembangkan dan memberi perhatian khusus pada tekonologi informasi sebagai sumber yang memfasilitasi pengumpulan dan penggunaan informasi secara efektif. Salah satu bentuk perhatian ini adalah penggunaan aplikasi sistem informasi keuangan berbasis komputer yang dikembangkan oleh BPKP yaitu Aplikasi SIMDA yang bertujuan untuk untuk membantu dalam penyusunan LKPD.

Secara umum, Sistem Informasi Manajemen (SIM) merupakan suatu sistem yang dapat membantu manajemen di dalam pengumpulan data, pengolahan serta analisis evaluasi data dan menyajikan ke dalam batas informasi yang bernilai dan akhirnya sampai pada pengambilan keputusan di mana informasi ini berguna untuk mendukung fungsi operasi manajemen (Machmud 2013). Aplikasi Sistem Informasi Manajemen Daerah yang dikembangkan oleh Badan Pengawasan Keuangan dan Pembangunan (BPKP) dan dikenal dengan Aplikasi SIMDA merupakan salah satu produk dari teknologi sistem informasi yang digunakan oleh banyak pemerintah daerah di Indonesia dalam menyelenggarakan pengelolaan keuangan daerahnya. (Djadja 2009) mendefiniskan Aplikasi SIMDA sebagai Aplikasi SIMDA adalah aplikasi yang dikembangkan oleh Badan Pengawasan Keuangan dan Pembangunan (BPKP), dimana tujuan dari pengembangan aplikasi ini adalah untuk mempercepat proses reformasi pengelolaan keuangan daerah. Hal ini dilatar belakangi oleh langkanya sumber daya manusia di pemerintahan daerah yang memiliki latarbelakang akuntansi, sehingga pemerintah daerah mengalami kesulitan dalam menyusun laporan keuangan sesuai dengan peraturan perundang-undangan yang berlaku.

Aplikasi SIMDA merupakan aplikasi database yang bertujuan untuk mempermudah pengelolaan keuangan daerah di lingkungan Satuan Kerja Perangkat Daerah (SKPD). Aplikasi SIMDA dikembangkan dengan memperhatikan dan mengimplementasikan Sistem Pengendalian Intern Pemerintah (SPIP). Oleh sebab itu pengendalian terhadap aplikasi menjadi suatu keharusan untuk menjadi pedoman bagi pemerintah daerah dalam mengimplementasikan Aplikasi SIMDA untuk menghasilkan Laporan Keuangan Pemerintah Daerah (LKPD) (Josvidar 2017). Aplikasi SIMDA telah terintegrasi mulai dari fungsi penganggaran, fungsi penatausahaan keuangan daerah, sampai fungsi akuntansi dan pelaporan. Maka dalam setiap implementasi suatu sistem berbasis komputer, perlu ditunjuk pihak yang berperan sebagai administrator. Administrator mempunyai fungsi untuk mengelola database, mengelola aplikasi (sotfware) dan hardware. Pada masing masing SKPD yang menjadi administrator adalah Pengguna Anggaran, Pejabat Penatausahaan Keuangan (PPK), Bendahara Pengeluaran, dan Pejabat Pengelola Teknis Kegiatan (PPTK) sebagai pengguna akhir (end users) dari Aplikasi SIMDA. Akselerasi reformasi pengelolaan keuangan daerah dapat berjalan efektif apabila fungsi-fungsi pengelolaan keuangan berjalan secara terintegrasi. Fungsi-fungsi tersebut adalah perencanaan, penganggaran, penatausahaan, serta pertanggungjawaban dan pelaporan (Halim 2002). 


\section{Metode}

Pendekatan yang digunakan dalam penelitian ini adalah pendekatan kualitatif (Neuwman 2006). Pendekatan kualitatif digunakan untuk mengetahui bagaimana eksistensi BPKP dalam pengawasan keuangan dan pembangunan di Indonesia. Khususnya dalam penelitian ini terkait dengan peran BPKP mengawasi dan mengarahkan implementasi SIMDA agar tepat sasaran seperti yang diharapkan. Berdasarkan tujuan penelitian, jenis penelitian ini termasuk dalam penelitian deskriptif yang memiliki perhatian menyajikan gambaran yang lengkap tentang peran BPKP dalam pengawasan implementasi SIMDA, serta eksistensi BPKP dalam melakukan pendampingan implementasi SIMDA Berdasarkan manfaat penelitian, penelitian ini termasuk dalam penelitian murni yang memiliki orientasi akademis dan ilmu pengetahuan yang menjelaskan langkah -langkah yang telah dilakukan BPKP perwakilan DIY dalam melaksanakan tugas kewajibanya sebagai upaya pengawasan di daerah wilayah kerjanya.

Sumber data sekunder yang digunakan merupakan telaah literatur-literatur yang berkaitan dengan tujuan penelitian. Selain itu data primer berupa hasil wawancara dengan pihak terkait, dalam hal ini peneliti melakukan diskusi dan wawancara dengan salah satu auditor senior pada bagian Akuntansi Pemerintah Daerah yang bernama bapak Yuli, beliau merupakan koordinator pada bagian tersebut. Sedangkan sebagai obyeknya adalah Pemerintah Daerah Kabupaten Kebumen Provinsi Jawa Tengah. Pemerintah daerah tersebut merupakan wilayah kerja dari Kantor BPKP Wilayah Provinsi Daerah Istimewa Yogyakarta.

\section{Teknik Analisis}

Dalam penelitian ini, analisis data yang dilakukan dengan mencari terlebih dahulu literatur-literatur yang relevan dengan topik penelitian. Literatur yang dikumpulkan berupa jurnal penelitian, buku dan berbagai literatur lainnya. Kemudian literatur tersebut dipahami dan ditelaah untuk menarik kesimpulan awal. Setelah data dikumpulkan kemudian dilakukan wawancara untuk memperoleh data dari catatan hasil wawancara. Dari data wawancara tersebut kemudian ditelaah dan diverifikasi kembali agar sesuai dengan konteks yang sebenarnya. Tahap terakhir data yang telah diurai sudah memberikan gambaran yang jelas mengenai permasalahan yang diteliti kemudian didukung oleh bukti-bukti yang valid dan konsisten saat penelitian dilakukan di lapangan. Setelah itu dapat dilakukan pengambilan kesimpulan yang digunakan untuk menjawab rumusan permasalahan.

Menurut (Emzir 2010) aktivitas analisis dan pengumpulan data tersebut akan membentuk siklus interaktif sebagai berikut:

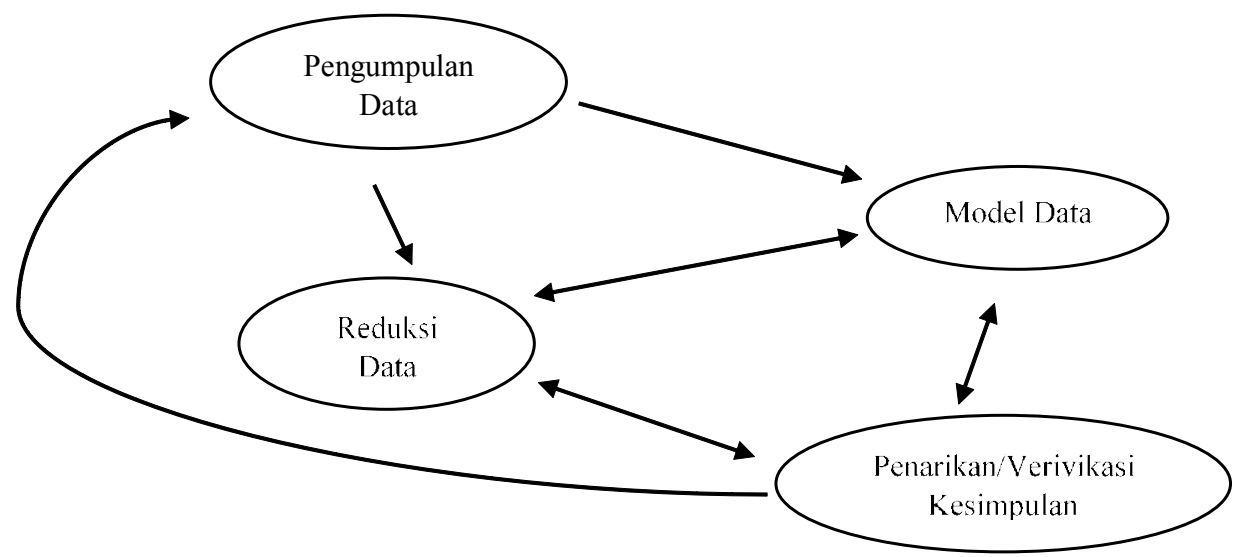




\section{Efektifitas \\ Peran \\ BPKP...}

956

\section{HASIL DAN PEMBAHASAN}

\section{Permasalahan Penggunaan SIMDA di Pemerintah Kabupaten Kebumen}

Hingga tahun 2016 Pemerintah Daerah Kabupaten Kebumen masih menggunakan dua SIMDA yaitu SIMDA Keuangan dan SIMDA BMD.

1. Permasalahan SIMDA Keuangan:

Dalam penyusunan Laporan Keuangan Pemerintah Daerah (LKPD) berbasis akrual, pemerintah daerah menggunakan aplikasi yang disediakan oleh Badan Pengawasan Keuangan dan Pembangunan (BPKP) yaitu Sistem Informasi Manajemen Daerah (SIMDA). SIMDA diperuntukan membantu pemerintah daerah dalam melaksanakan pengelolaan keuangan daerah. Perwakilan BPKP DIY memiliki peran dalam melakukan pendampingan terhadap pemerintah daerah dalam proses updating SIMDA.

Temuan yang kedua terjadinya perbedaaan kas di neraca dan BKU pada beberapa SKPD. Hal ini terjadi karena saat pengeluaran kas oleh Bendahara Pengeluaran melalui menu Bukti Pengeluaran, tidak terbentuk jurnal Uang Muka operasional pada Kas di Bendahara Pengeluaran, sehingga uang sudah keluar di BKU namun belum di kredit pada Buku Besar Kas Bendahara Pengeluaran.

Dalam proses pendampingan tersebut Tim Auditor juga menemukan beberapa temuan dalam kesalahan penyusunan LKPD. Temuan yang pertama adanya duplikasi bukti tagihan SPP di beberapa SKPD (nomor bukti tagihan yang sama dipakai pada beberapa SKPD). Akibatnya bukti tagihan dengan nomor sama yang terakhir diinput ke aplikasi SIMDA Keuangan, tidak terbentuk jurnal akrual.

Temuan yang ketiga terjadinya kesalahan pemilihan jenis tagihan belanja saat pembuatan SPP-LS. Belanja modal menggunakan jenis tagihan operasional atau pembiayaan dan belanja operasional menggunakan jenis tagihan belanja modal atau pembiayaan, hal ini mengakibatkan jenis beban tidak sesuai dengan jenis belanjanya dan mengakibatkan laporan operasional (LO) tidak menyajikan angka yang akurat.

2. Permasalahan SIMDA Barang Milik Daerah (BMD):

Kebijakan akuntansi pada SIMDA BMD tidak berjalan dengan normal, masih terdapat barang di bawah nilai batas kapitalisasi masuk ke buku intrakomptable dan tercatat sebagai aset tetap di neraca. Selain itu, terdapat barang dengan kondisi rusak berat yang masih tercatat di buku intrakomptable walaupun pada neraca sudah tercatat di aset lainnya. Belum lengkapnya menu pencatatan penyusutan barang pada SIMDA BMD menjadi temuan permasalahan pada Kabupaten Kebumen khusunya permaslahan pengakuan penyusutan barang. Temuan ini sama dengan hasil penleitian yang telah dilakukan oleh (Supriyanto 2015) bahwa aplikasi tersebut terdapat kekurangan yaitu prosedur akutansi belum dapat diterapkan karena fungsi sub menu penyusutan belum diakomodir.

Permasalahan lain yang memerlukan tindak lanjut dari Pemerintah Kabupaten Kebumen, yaitu antara lain pada Peraturan Bupati Kebumen nomor 21 tahun 2014 tanggal 30 Mei 2014 tentang Sistem Akuntansi Pemerintah Daerah (SAPD) belum menyesuaikan dengan Buletin Teknis nomor 13 tentang Akuntansi Hibah dan 14 tentang Akuntansi Kas lainnya.

Kedua tentang Peraturan Bupati Kebumen Nomor 20 tahun 2014 tanggal 15 Desember 2014 tentang Kebijakan Akuntansi belum menyesuaikan IPSAP Nomor 4 tentang perubahan akuntansi dan koreksi kesalahan tanpa penyajian kembali laporan keuangan.

Ketiga, belum dibuat SOP atas penghapusan sebagian aset tetap yang melibatkan SKPD teknis dan atribusi biaya perolehan aset tetap, khususnya pada 
SKPD yang memiliki UPT. Temuan BPK perwakilan Jawa Tengah atas LKPD tahun 2014 menyebutkan Pemerintah Kabupaten Kebumen belum melaksanakan penghapusan sebagian atas aset tetap yang mengalami perbaikan/ rehabilitasi.

\section{Peran Perwakilan BPKP DIY}

Berdasarkan permasalahan yang ditemukan oleh pihak BPKP perwakilan DIY pada Pemerintah Kabupaten Kebumen, maka BPKP perwakilan DIY melakukan pendampingan yang mencakup kegiatan pemberian materi, kegiatan diskusi dan pembimbingan aplikasi SIMDA keuangan sebagai berikut:

1. Bimbingan Teknis berupa pendampingan kepada SKPD serta Bidang Aset dan Akuntansi DPPKAD meliputi pencatatan jurnal balik, penerapan buletin teknis SAP nomor 13 \& nomor 14 terkait dana Bantuan Operasional Sekolah (BOS), dan pendampingan perhitungan penyusutan aset tetap melalui aplikasi SIMDA BMD versi 2.6.9

2. Penggabungan data Surat Ketetapan Pajak Daerah (SKPD) khususnya Pajak Reklame dan Pajak Air Tanah yang diterbitkan dari aplikasi pendapatan daerah (MAPADA) dengan aplikasi SIMDA keuangan versi 2.7.0.7. Penggabungan dilakukan dengan cara mengolah output aplikasi MAPADA dan menstrukturkan output tersebut sesuai database SIMDA Keuangan, kemudian melakukan rebuild agar dihasilkan jurnal-jurnal akuntansi pembentuk piutang pendapatan dan pendapatan-LO.

3. Melakukan beberapa revisi tentang informasi akuntansi berupa:

a. Memperbaiki rincian nilai SPP pada database SIMDA Keuangan

b. Merubah nomor tagihan pada database SIMDA Keuangan

c. Melaksanakan rebuild atas nomor bukti pengeluaran yang belum terbentuk jurnalnya.

d. Merubah jenis tagihan pada database SIMDA Keuangan

4. Pembuatan laporan terhadap hasil pendampingan di Pemerintah Kabupaten Kebumen serta melakukan pendampingan proses migrasi dan updating database SIMDA Keuangan versi 2.7.0.5 menjadi SIMDA Keuangan 2.7.0.7.

BPKP perwakilan DIY juga melakukan tindak lanjut terkait dengan Peraturan Bupati Kebumen nomor 21 tahun 2014 tentang Sistem Akuntansi Pemerintah Daerah (SAPD) dengan mengakomodir buletin teknis SAP nomor 13 dan nomor 14 dengan menyarankan Kepala DPPKAD untuk membuat usulan revisi peraturan bupati tentang SAPD Kabupaten Kebumen. Revisi Peraturan Bupati Kebumen nomor 20 tahun 2014 tentang kebijakan akuntansi juga diterapkan untuk disesuaikan dengan IPSAP nomor 4 tentang perubahan akuntansi dan koreksi kesalahan tanpa penyajian kembali laporan keuangan. Untuk permasalahan tentang SOP atas penghapusan sebagian aset tetap, BPKP melakukan koordinasi teknis untuk setiap SKPD untuk melakukan perhitungan nilai penghapusan sebagian atas aset tetap. Melalui proses penyempurnaan peraturan Bupati tersebut BPKP perwakilan DIY telah melakukan pengawasan dan pemantauan atas implementasi SIMDA di Kebumen. Menurut (Josvidar 2017) menjelaskan bahwa pengaruh pengawasan dan pemantauan menentukan tingkat keberhasilan implementasi SIMDA.

\section{Analisis}

Berdasarkan hasil pengumpulan informasi dari informan yang dipilih, ditemukan bahwa permasalahan yang dihadapi BPKP dalam upaya implemantasi SIMDA diawali dengan kurang maksimalnya penggunaan beberapa aplikasi SIMDA. Kabupaten Kebumen sebagai pengguna aplikasi SIMDA belum sepe- 
Efektifitas

Peran

BPKP...

958 nuhnya menggunakan secara optimal, mereka hanya menggunakan dua aplikasi SIMDA yaitu SIMDA Keuangan dan SIMDA BMD. Menurut BPKP seharusnya setiap pemda mampu menggunakan semua konsep SIMDA dari BPKP yaitu SIMDA Keuangan, SIDMA BMD, SIMDA Gaji dan SIMDA Pendapatan. Hal ini yang menyebabkan penerapan SIMDA oleh SKPD belum dapat membantu mencapai tujuan organisasi pemda secara maksimal.

Kedua kurangnya kesiapan menerima dan mengaplikasikan software terintegrasi untuk melakukan prosedur akuntansi. Para personel yang terlibat dalam implementasi SIMDA dianggap masih kurang. Sehingga perlunya dukungan semua pihak dalam proses aplikasinya termasuk peran dari manajemen puncak. Kondisi tersebut seperti yag diungkapkan oleh (Yurniwati \& Rizaldi 2015) menjelaskan bahwa pentingnya kemampuan kepemimpinan dari pucuk pimpinan SKPD dalam proses implementasi SIMDA. Kurangnya totalitas dalam proses implementasi SIMDA ditunjukkan dengan kurangnya SOP dan Peraturan pemerintah daerah yang menjadi dasar dan petunjuk implementasi SIMDA di Kabupaten Kebumen.

Ketiga, menurut BPKP kemampuan penguasaan pengoperasian SIMDA yang belum merata di setiap SKPD, software ini menuntut penggunanya tidak hanya fasih dalam akuntansi tetapi juga dalam penggunaan komputer.

Terakhir, karena keterbatasan kompetensi sumber daya manusianya sehingga masih banyak ditemukan pegawai yang lebih memilih menggunakan kertas kerja manual atau dengan Ms.Excell untuk menyelesaikan pekerjaannya yang dirasa lebih mudah daripada menggunakan SIMDA. Seperti yang dikemukanan oleh (Alfian 2015) bahwa tingkat pemahaman pengguna SIMDA memiliki pengaruh positif terhadap kualitas implementasi SIMDA. Sehingga perlu dilakukan pembinaan terkait perubahan pola pikir yang tadinya semua dikerjakan secara manual harus dirubah menjadi memahami pentingnya penggunaan sistem terkomputerisasi terintegrasi dalam proses pelaporan keuangan.

BPKP wilayah DIY telah melakukan berbagai upaya agar berbagai masalah tersebut dapat terselesaikan dengan baik. Berdasarkan informasi yang diperoleh BPKP wilayah DIY telah melakukan sosialisasi, asistensi, evaluasi serta bimbingan teknis terhadap pengelola SIMDA SKPD Kebumen. Kegiatan pengawasan dan evaluasi tersbut dilakukan terhadap pimpinan hingga operator yang melaksanakan administrasi pelaporan keuangan SKPD tersebut. Namun hasil penelitian ditemukan hambatan dalam pengawasan dimulai dari SDM, anggaran untuk melakukan pengawasan, sarana dan prasarana yang digunakan untuk melakukan pengawasan, serta metode kerja dalam proses pengawasan dan evaluasi.

SDM merupakan faktor utama dalam pengawasan karena jika tidak ada SDM yang terjadi adalah tidak akan ada proses pengawasan. Permasalahan SDM di BPKP menjadikan salah satu penyebab kurang efektifnya pengawasan dan evaluasi tidak berjalan dengan cepat hal ini dikarenakan adanya jumlah yang tidak sebanding antara jumlah pegawai dengan jumlah daerah yang ditangani. Dalam praktiknya pegawai BPKP dapat menangani lebih dari 10 dinas SKPD dan beberapa modul SIMDA yang harus didampingi dan dievaluasi dalam satu tahun kinerjanya, kondisi seperti ini dirasa tidak ideal dalam pelaksanaan proses evaluasi program-program BPKP. Akibatnya banyak SDM yang tidak mampu segera menyelesaikan permasalahan dikarenakan harus menyelesaikan permasalahan yang lain. Keterbatasan jumlah SDM di BPKP mengakibatkan terlaksananya kegiatan monitoring dan evaluasi program-program BPKP hanya dilakukan terkonsentrasi di beberapa daerah dan di beberapa program saja, sehingga pelaksanaan pengawasan dan evaluasi belum merata di seluruh daerah dan di seluruh program-program BPKP. Proses pengawasan dan evaluasi dilakukan dengan jumlah frekuensi yang tidak berimbang baik di daerah-daerah maupun program-program tertentu saja. Masih banyak SDM yang belum mampu menentukan skala prioritas atas beberapa program yang harus diselesaikan. Sehingga diperlukan kemampuan untuk menentukan prioritas permasalahan yang harus diselesaikan. Kurang idealnya kondisi SDM di BPKP sesuai dengan harapan peneli- 
tan yang dilakukan oleh (Wuysang et al. 2016) yaitu BPKP sebaiknya mempertimbangkan untuk kebutuhan-kebutuhan dalam rangka optimalisasi kinerja organisasi meliputi pemerataan kuantitas SDM dari segi jumlah personil yang dimiliki yang disesuaikan dengan analisis beban kerja serta peningkatan kapasitas SDM melalui diklat dan sertifikasi.

Permasalahan kedua yaitu anggaran. Anggaran menjadi faktor penentu dalam kegiatan atau aktivitas pengawasan. Walaupun bukan semata-mata faktor utama yang menjadi ukuran keberhasilan kegiatan pengawasan, tetapi faktor ini menjadi penting manakala lembaga-lembaga pengawas ingin melakukan kegiatannya serta menyukseskan kegiatan pengawasan. Hal ini disebabkan anggaran merupakan modal untuk membiayai seluruh kegiatan pengawasan, mulai dari biaya yang dikeluarkan untuk melakukan pengawasan, biaya akomodasi, dan beban honorarium atas aparat-aparat yang melakukan pengawasan, pengadaan barang dan jasa di bidang pengawasan, hingga peningkatan kinerja bagi aparat-aparat peng-awas itu sendiri. Anggaran juga digunakan untuk pembelian sarana prasarana yang mendukung proses pengawasan. Terdapat beberapa sarana dan prasana yang terkadang mengganggu proses pengawasan misalnya, laptop dan PC yang akan digunakan mengalami gangguan, kondisi tersebut memperlambat proses pengawasan dan evaluasi program dan daerah-daerah yang akan dimonitoring dan dievaluasi. Untuk pengadaan sendiri terkadang harus melalui proses yang panjang dan lama sehingga menganggu kinerja proses pengawasan dan pembinaan. Menurut (Wuysang et al. 2016) menjelaskan bahwa harapan maksimalisasi anggaran yang memadai digunakan sebagai upaya peningkatan kesejahteraan auditor dengan basis kinerja, dan fasilitas-fasilitas (tools and equipment) penunjang dalam melakukan penugasan secara khusus di Perwakilan BPKP. Permasalahan anggaran ini menjadi hambatan efektifitas pengawasan karena BPKP sebagai lembaga pengawas ingin melakukan kegiatan pengawasan namun anggaran yang diberikan tidak cukup memadai untuk melaksanakan kegiatan tersebut. Adanya keterbatasan anggaran juga mengakibatkan permasalahan pada peningkatan kinerja aparat-aparat, problematika yang muncul adalah BPKP tidak mampu membiayai keseluruhan aparat tersebut yang menginginkan peningkatan kinerjanya dengan menempuh pendidikan baik di dalam maupun di luar negeri. Kurang optimalnya anggaran yang dimiliki oleh BPKP akan berdampak pada kurang efektifnya proses pengawasan dan pengendalian proses implmentasi SIMDA.

Permasalahan berikutnya adalah metode kerja, perubahan metode kerja menjadi salah satu penghambat efektifitas kinerja pegawai BPKP dalam proses pengawasan dan pembinaan di daerah-daaerah. Beberapa aparat-aparat yang sudah terbiasa dengan tempat nyaman dan pola pola kerja yang sudah terbiasa dan membudaya tidak ingin pindah dan berganti pola kerja. Padahal dengan tuntutan pekerjaan yang lebih maju sangat mempengaruhi kinerja karyawan BPKP. Metode kerja yang sekarang diterapkan oleh BPKP adalah metode kerja yang menuntut SDM tidak hanya memiliki keahlian di dalam satu bagian saja, melainkan dibutuhkan integritas dari SDM untuk memahami tuntutan zaman. SDM yang telah terbiasa dengan metode kerja yang lama menjadi kendala dalam lembaga BPKP karena ketika perubahan metode kerja diperlukan untuk perbaikan kinerja, pola pikir SDM sulit untuk dirubah. Bahkan, tidak jarang kinerja BPKP menjadi menurun akibat proses perubahan tersebut. Dalam proses evaluasi dan monitoring program SIMDA dibutuhkan pola kinerja yang tidak teratur karena dihadapkan pada kondisi yang tidak diperkirakan sebelumnya, misalnya dalam imlementasi SIMDA terjadi kesalahan entri yang kemungkinan sebelumnya belum diprediksi sehingga harus melakukan perubahan menyeluruh atas proses sebuah sistem yang telah diaplikasikan. Hal ini sangat menggangu scara psikologis seorang karyawan BPKP, jika karyawan tersebut tidak memahami pola-pola perubahan metode pekerjaan bukan tidak mungkin terjadi ketidakefektifan proses evaluasi programprogram di BPKP termasuk didalamnya proses implementasi SIDMA BPKP. Pada kenyataannya masih terdapat beberapa SDM yang masih belum menerima per- 
Efektifitas

Peran

BPKP...

960

ubahan kerja bahkan kadang kala terjadi penolakan terhadap apa yang dikerjakannya sehingga dapat menyebabkan performance yang dimilikinya menurun seiring menurunnya kepuasan kerja. Hal ini menyebabkan kinerja pada bagian tersebut juga mengalami kemunduran jika SDM tersebut berpengaruh secara signifikan. Bahkan bisa jadi pada skala BPKP itu sendiri akan menyebabkan kinerjanya menurun.

\section{SIMPULAN}

Proses implementasi aplikasi SIMDA oleh daerah sangat terpengaruh oleh keadaan internal daerah tersebut, salah satunya yang terjadi pada Pemda Kebumen. Dalam proses implementasi SIMDA di Pemda Kebumen ternyata terdapat permasalahan yang cukup banyak. Permasalahan tersebut adalah, pertama Pemda Kebumen belum total dalam proses implementasi aplikasi SIMDA. Mereka hanya memilih beberapa bagian modul saja yaitu modul SIMDA keungan dan SIMDA BMD. Menurut BPKP efektifitas aplikasi SIMDA sangat terpengaruh dari kinerja seluruh modul yang dibuat oleh BPKP. Kedua, kurangnya dukungan dari seluruh elemen termasuk didalamnya dukungan pucuk pimpinan lembaga tersebut. Ketiga, rendahnya SDM terkait kemampuan penggunaan sistem teknologi khusunya aplikasi SIMDA. Masih banyak SDM yang terbiasa menggunakan sistem manual. Keempat, kurangnya pemahaman SDM terkait perubahan pola kerja yang diakibatkan oleh implementasi SIMDA. Mereka masih terbiasa dengan pola-pola lama yang mengandalkan banyak kertas dalam proses pelaporan keuangan.

Untuk mengatasi beberapa permasalahan tersebut, BPKP perwakilan DIY telah melakukan beberapa aktivitas pengawasan dan pembinaan terhadap proses implementasi aplikasi SIMDA. Aktivitas tersebut adalah sosialisasi dan bimbingan, pengawasan, pendampingan, serta monitoring dan evaluasi. Namun pelaksanaan aktivitas tersebut terdapat beberapa permasalahan yang mengurangi efektifitas proses pengawasan BPKP. Hambatan tersebut yaitu, pertama permasalahan SDM yang dimiliki Kantor Perwakilan BPKP DIY. Jumlah SDM yang ada tidak sebanding dengan jumlah program-program di daerah, hal ini sedikit mempengaruhi efektifitas kinerja pengawassan BPKP. Kedua permasalahan anggaran, anggaran yang ada saat ini dirasa kurang mendukung proses pengawasan dan evaluasi program-program BPKP. Dalam proses visitasi pengawasan ke daerah-daerah membutuhkan anggaran yang tidak sedikit termasuk pembelian sarana dan prasarananya. Adanya permasalahan tersebut mengindikasikan adanya pengaruh efektifitas pengawasan BPKP terhadap proses pengawasan dan evaluasi aplikasi SIMDA. Perubahan pola kerja menjadi temuan permasalahan terakhir yang terungkap dalam penelitian ini. Beberapa SDM yang ada di BPKP ternyata sulit untuk melakukan perubahan terhadap pola kerja baru. Dalam proses implementasi SIMDA tuntutan untuk melakukan perubahan pola kerja sangat dianjurkan, karena SIMDA selain merubah pola kerja SDM di daerah-daerah juga merubah pola kerja dan pola pikir karyawan dan auditor BPKP.

Penelitian ini menggambarkan efektifitas kinerja BPKP Kantor Wilayah DIY dalam melakukan pengawasan dan evaluasi SIDMA di Pemda Kebumen. Hasilnya cukup efektif meskipun terdapat beberapa kendala dalam proses pengawasan tersebut. Namun dalam penelitian ini masih perlu dukungan dari penelitian lain yang bertujuan untuk menilai efektifitas kinerja BPKP di beberapa wilayah yang lain untuk memberikan gambaran menyeluruh bagi kinerja BPKP di seluruh Indonesia.

\section{DAFTAR PUSTAKA}

AAIP, Asosiasi Auditor Intern Pemerintah., 2013. Standar Audit Intern Pemerintah Indonesia, 
Alfian, M., 2015. Faktor pendukung implemetasi simda dan pengaruhnya terhadap kualitas laporan keuangan pada skpd kabupaten kulon progo. 3rd Economics \& Business Research Festival UKSW, XVIII(3), pp.119-131.

BPKP, Pengenalan Sistem Informasi Manajemen Daerah (SIMDA). Available at: http://www.bpkp.go.id/sakd/konten/333/Versi-2.1.bpkp.

Djadja, S., 2009. Pemahaman Laporan Keuangan dengan SIMDA Keuangan., Jakarta: Deputi Pengawasan Bidang Penyelenggaraan Keungan Daerah.

Emzir, 2010. metodologi penelitian kualitatif/ : analisis data, Jakarta: rajawali pers.

Gunawan, S., 2007. Kajian Kinerja Lembaga Pengawasan Daerah, Bandung: PKP2A I LAN.

Halim, A., 2002. Akuntansi Sektor Publik/:Akuntansi Keuangan Daerah, Jakarta: Salemba Empat.

Josvidar, N., 2017. Pengaruh Sistem Pengendalian Intern Pemerintah Terhadap Efektivitas Sistem Informasi Manajemen Daerah (Simda) Keuangan (Survey Pada SKPD Pemerintah Kabupaten Sigi). e Jurnal Katalogis, 5(2), pp.92103.

Machmud, R., 2013. Hubungan Sistem Informasi Manajemen dan Pelayanan dengan Kinerja Pegawai pada Rutan Makassar. Jurnal Capacity STIE AMKOP Makassar, 1(oktober), pp.78-85.

Neuwman, L., 2006. Social Research Methods: Qualitative and Quantitativele Approach Sixth Edit., New York: Pearson Education Inc.

Nuraeni, 2010. Analisis Pengaruh Karakteristik Pemerintah Daerah Terhadap Kualitas Audit Laporan Keuangan Pemerintah Kabupaten/Kota Tahun 20082009. Universitas Indonesia.

Peraturan Pemerintah No 60 tahun 2008 pasal 59 ayat (2) dan Inpres Nomor 4 Tahun 2011 Tentang Sistem Pengendalian Intern Pemerintah

Peraturan Pemerintah No.71 Tahun 2010 Tentang Standar Akuntansi Pemerintahan Berbasis Akrual

Peraturan Menteri Dalam Negeri No 64 tahun 2013 Tentang Penerapan Standar Akuntansi Pemerintahan Berbasis Akrual Pada Pemerintah Daerah

Supriyanto, S., 2015. Analisis Implementasi Sistem Informasi Manajemen Daerah (SIMDA) Barang Milik Daerah. Jurnal Akuntansi Universitas Jember, 13(2).

Wicaksono, P.T., 2012. Analisis Faktor-faktor yang Mempengaruhi Opini dan Temuan Audit BPK atas LKPD Kabupaten/Kota di Indonesia Tahun 20082009. Universitas Indonesia.

Wuysang, R.V.O., Nangoi, G. \& Pontoh, W., 2016. Analisis Penerapan Akuntansi Forensik Dan Audit Investigatif Terhadap Pencegahan Dan Pengungkapan Fraud Dalam Pengelolaan Keuangan Daerah Pada Perwakilan Bpkp Provinsi Sulawesi Utara. Journal of Accounting Forensic, pp.31-53.

Www.bpkp.go.id,

Yurniwati \& Rizaldi, A., 2015. Control Environment Analysis at Government Internal Control System: Indonesia Case. Procedia - Social and Behavioral Sciences, 211(September), pp.844-850. Available at: http://linkinghub. elsevier.com/retrieve/pii/S1877042815054518. 
